\title{
Koetun koulutustarpeen intensiteetin selittäminen tutkimuksen tavoitteena
}

Koetusta koulutustarpeesta ja sitä selittävistä tekijöistä. Helsingin yliopiston kasvatustieteen laitoksen tutkimuksia 121. Väitöstilaisuudessa pidetty 3.11.1989 Helsingin yliopistossa pidetty lectio.

Koulutustarpeen selvityksessä on Kaufmanin ja Englishin (1979) sekä Forsbergin (1986) mukaan — käytettävissä kaksi vaihtoehtoista mutta sisäkkäistä lähestymistapaa. Laajempaa lähestymistapaa kutsutaan tässä ulkoiseksi tarvearvioinniksi ja suppeampaa sisäiseksi tarvearvioinniksi.

Ulkoisessa tarvearvıoınnissa selvitetään, esiintyykö ylipäätään koulutuksen tarvetta ja jos esiintyy, niin millaisen. Aikuiskoulutukseen osallistumishalukkuutta selvittäneet tutkimukset ovat usein edustaneet ulkoista tarvearviointia: tiedustellaan yksilöiltä, minkä sisältöiseen ja muotoiseen koulutukseen he olisivat halukkaita osallistumaan.

Toisenlaista ulkoista tarvearviointia hyödyntänyttä lähestymistapaa edusti kirjoittajan aiempi tutkimus (1985a), jossa selvitettiin yksilöiden muutoshalukkuutta ja heidän kokemiensa kehittymispyrkimysten suuntaa. Tämän vaihtoehdon ongelmaksi osoittautui irtaantuminen konreetista koulutustoiminnasta - yksilön ilmaisemien kehittymispyrkimysten ja hänen kokemansa koulutustarpeen yhteys on ilmeisesti etäinen. Sisäisessä tarvearvioinnissa tiedetään, millaista koulutusta järjestetään. Koulutuksen suunnittelun perusoletuksena on, että tietyn kaltaiseen koulutukseen esiintyy tarvetta. Koulutustarpeen selvityksen avulla pyritään näin luomaan pitävä perusta koulutuksen sisällölliseen suunnitteluun. Siten koulutustarpeen selvitys sisäisessä tarvearvioinnissa on osa koulutuksen suunnittelun prosessia ulkoisen tarvearvioinnin ehdoin toteutettu koulutustarpeen selvitys sitä vastoin muodostaa koulutuksen suunnittelun lähtökohdan.

Yksilön kokeman koulutustarpeen selvitys sisäisenä tarvearviointina tuottaa jo toteutettavaksi ajatellun koulutuksen sisällöllistä suunnittelua palvelevia tietoja. Kuitenkin eräissä tapauksissa saattaa yksilön kokema eli koettu koulutustarve luonteensa tai painotuksensa vuoksi myös vaikuttaa koulutuksen opetus-oppimismenetelmällisiin rátkaisuihin.
Nykyisessä koettua koulutustarvetta käsittelevässä kirjallisuudessa on erotettavissa useita erilaisia tapoja määritellä koettu koulutustarve. Jos koettu koulutustarve hahmotetaan osallistumishalukkuudeksi tai koulutuskysynnäksi, pyritään yleensä ulkoisen tarvearvioinnin tuottamaan, koulutuksen tarpeellisuutta käsittelevään tietoon.

Scissons (1982) on esittänyt, että koulutustarve voidaan jakaa pätevyyteen, motivaatioon ja asiaankuuluvuuteen. Suomennokset ovat Vahervan (1986). Kirjoittaja on itse nimennyt ne valmiuksien koetuksi riittävyydeksi, kiinnostuneisuudeksi ja tarpeellisuudeksi.

Mikäli Scissonsin näkemyksiä pyritään hyödyntämään koetun koulutustarpeen tarkasteluun, on perusteltua pitää kiinnostuneisuutta, tarpeellisuutta ja valmiuksien koettua riittävyyttä arviointiperustoina, joita yksilö voi käyttää arvioidessaan kokemaansa koulutustarvetta.

Koettu koulutustarve on tällöin määriteltävissä yksilön tiettyyn oppiainekseen kohdistamiksi arvioinneiksi, jotka voivat ohjautua yhdestä tai useammasta arviointiperustasta.

Niiniluodon $(1983,266)$ mukaan selvitykset ovat vastauksia selityskysymyksiin, joita on useamman luonteisia. Voidaan esimerkiksi kysyä:

1. Selitä, mitä koettu koulutustarve tarkoittaa.

2. Selitä, millainen on kohderyhmän kokema koulutustarve.

3. Selitä, miten koettu koulutustarve liittyy koulutuksen suunnitteluun.

Niiniluodon mukaan (emt.) tällaisissa selityskysymyksissä on kyse esineen, systeemin, tavan tai toiminnon kuvailemisesta.

1. Selitä, miksi koettua koulutustarvetta esiintyy.

2. Selitä, miksi näkemykset kasvatuksen vaikuttavuudesta ovat yhteydessä koettuun koulutustarpeeseen.

3. Selitä, mikä merkitys koetulla koulutustarpeella on yksilön kannalta.

Selityskysymykset edellyttävät tällöin tapahtuman tai ilmiön geneettistä, kausaalista tai funktionaalista selittämistä.

Kun otsikon virittämään ongelmaan pyritään vastaamaan, tarkoitetaan selittämisen käsitteellä jälkimmäistä selityskysymysten ryhmää. 
Lisäksi tehdään vielä seuraava rajaus: Selityskysymykset voidaan jakaa perusteita tai selitystä etsiviin. Edelliset kyseenalaistavat taustaoletuksia "miksi olisi niin, että koulutustarve liittyy koulutuksen suunnitteluun". Jälkimmäiset taas kysyvät "miksi kohderyhmän kokeman koulutustarpeen intensiteetti on sellainen kuin on".

Mielenkiinnon kohteena tässä ovat selitystä etsivät kysymykset. Siten eräät perusoletukset oletetaan vallitseviksi.

Esitetyssä merkityksessä on koetun koulutustarpeen tutkimuksissa sen selittäminen harvoin nostettu tutkimuksen tavoitteeksi. Tämä on ymmärrettävää sillä kuvausta hakevat selityskysymykset ovat dominoineet tutkimuskenttää; perusilmiön jäsennyksessä on kulunut aikansa.

Useampaa koulutustarpeen arviointiperustaa hyödyntävän lähestymistavan avulla kyetään kuvaamaan koettua koulutustarvetta moniulottesesti kulloinkin kyseessä olevan koulutuksen suunnittelutilanteen vaatimusten mukaisesti. Jos arviointiperustat operationalisoidaan yhtenevästi eri tutkimuksissa, saavutetaan kuitenkin myös aiempaa parempi koulutustarvetta kuvailevien käsitteiden yhteismitallisuus. Näin perusta selittävämpään tutkimusotteeseen siirtymiselle on olemassa.

Nykyisen teorianmuodostuksen ja tutkimukseni perusteella nousee kolme ongelmaa koetun koulutustarpeen selittämisessä esiin. Kutakin käsitellään vuorollaan.

Yksilö ilmentää kokemaansa koulutustarvetta reagoimalla ärsykkeisiin, jotka potentiaalisesti oletaan hyödyllisiksi koulutussisällöiksi. Ärsykeaines on - mikäli on kyse sisäisestä tarvearvioinnista - tiettyyn toimintatodellisuuteen sitoutunutta eli tilannesidonnaista.

Reaktion intensiteettiä selitettäessä voitaneen ilmeisesti erottaa tekijät, jotka liittyvät kulloinkin kyseessä olevan kohderyhmän spesifeihin piirteisiin sekä arvioitavaan ärsykeainekseen. Näiden vaikutus on todennäköisesti tilannesidonnaista ja vaihtelee koetun koulutustarpeen selvityksen myötä.

Toisaalta on myös tekijöitä, joiden vaikutuksen voi olettaa pysyvän samankaltaisena koetun koulutustarpeen selvityksestä toiseen. Siten ne ovat yleisempiä tekijöitä, jotka altistavat kokemaan koulutustarpeen tietyllä tapaa.

Koetun koulutustarpeen intensiteettiä selitettäessä on siten ongelmana, kuinka yleistettävään selitykseen pyritään. Ongelma nivoutuu toiseen ongelmaan, joka nimetään koetun koulutustarpeen sisältöriippuvuuden ongelmaksi.

Tutkimusekonomisesti on harvemmin mielekästä pyrkiä yhdessä ja samassa tutkimuksessa monipuoliseen kuvaukseen ja selitykseen. Koulutustarvetutkimuksia pyritään yleen- sä hyödyntämään välittömästi koulutuksen suunnittelussa - käytännöllisesti painottunut tavoite korostaa koulutustarpeen kuvausta.

Mikäli painotetaan kuvausta voimakkaasti, vältetään yleistyksiä ja tutkimuksen kohderyhmän koulutustarve kuvataan käytettyjen yksittäisten koulutustarvemuuttujien avulla. Jos taas painotetaan selittämistä, kuvataan koulutustarve äärimuodossaan yhden mittaluvun avulla ja arvioidaan sen yhteyksiä selittäviin muuttujiin. Kyse on näin induktiivisen ja deduktiivisen otteen tasapaino-ongelmasta.

Yleinen ongelman ratkaisutapa on niin sanotun faktoritason tarkastelu. Faktoritason tulokset eivät kuitenkaan yleensä ole yksittäisen tutkimuksen kohderyhmää laajemmin yleistettävissä, sillä ne ovat sidoksissa tietyn kohderyhmän tietyssä tilanteessa kokeman koulutustarpeen sisältöön.

Tutkimuksessani (1989) kuvasin koulutustarvetta sekä yhden että useamman mittaluvun avulla. Tällöin ilmeni, että varsinkin näkemykset kasvatuksen vaikuttavuudesta selittävät koulutustarpeen intensiteettiä. Se korreloi voimakkaimmin koettuun koulutustarpeeseen silloin, kun koulutustarve kuvataan tarpeellisuuden ja kiinnostuneisuuden summana $(.42, \mathrm{n}=$ 188).

Mikä selittää mainitun yhteyden? On luultavaa, että arvioidessaan tietyn ainessisällön tarpeellisuutta tai kiinnostavuutta, yksilö joutuu suorittamaan vaativan päättelyn. Aiemmassa tutkimuksessani (Varila 1985b) olen esittänyt, että yksilön arvioinnit perustuvat hänen elämäntodellisuutensa diagnostisointiin, muutossuunnan ja kehittymispyrkimysten hahmottamiseen sekä kasvatuksen ja koulutuksen vaikuttavuuden arviointiin. Nämä ovat tehtäviä, jotka ovat vaativia kasvatusalan tutkijallekin.

Koulutustarpeen tarpeellisuus- ja kiinnostuneisuusarvioinnit ovat luonteeltaan yksilön tulevaisuuteen suuntaamia projektioita. Näin tarpeellisuus- ja kiinnostuneisuusarvioinnit välittyvät (taittuvat) yksilön asennoitumis- ja tulkitsemisprosesseissa. Tällöin on luonnollista, että yksilön näkemykset kasvatuksen vaikuttavuudesta selittävät tarpeellisuus- ja kiinnostuneisuusarviointien intensiteettiä. Aiemman koettua koulutustarvetta selittävän tutkimuksen harvalukuisuuden vuoksi on kyseinen tulos tutkijan tietojen mukaan kuitenkin uusi.

Esitettyä tulkintamallia puoltaa se, että kasvatuksen vaikuttavuus ei ole yhteydessä valmiuksien koettuun riittävyyteen. Tulos selittyy siten, että valmiuksien riittävyyden arviointi perustuu jo elettyyn ja koettuun todellisuuteen. Näin on luonnollista, etteivät riittävyysarvioinnit taitu asennoitumis- ja tulkitsemisprosesseissa samalla tavoin kuin tarpeellisuus- ja kiinnostuneisuusarvioinnit. Riittävyysarviointien perusta on menneisyydessä, jo eletyssä ja 
koetussa kun tarpeellisuus- ja kiinnostuneisuusarviointien perusta on tulevaisuudessa.

Kolmas koetun koulutustarpeen selittämiseen liittyvä ongelma on laaja-alaisempi. Aikuiskasvatuksessa on usein kysytty, miksi koulutuksellisesti huonompiosaiset eivät koe koulutustarvetta. Oallistumistutkimuksissa on kysymykseen esitetty runsaasti vastausehdotuksia; demografisilla ja sosioekonomisilla muuttujilla on kyetty kuvaamaan mekanismeja on selvitelty vähän.

On luultavaa, että näkemykset kasvatuksen vaikuttavuudesta ovat yksi sosiodemografisten tekijöiden vaikutusta välittävä mekanismi. Kerrostumaspesifissä sosialisaatiossa muokkautuvat perusnäkemykset kasvatuksen ja koulutuksen toiminta-alasta ja vaikuttavuudesta.

Siten on mahdollista, että koetun koulutustarpeen käsite jo itsessään suosii koulutuksellisesti hyväosaisia. Mitä enemmän ihminen on kouluttanut itseään, sen laaja-alaisemmaksi hän kasvatuksen ja koulutuksen vaikuttavuuden arvioi — ja sitä todennäköisemmin arvio on osuva. Samoin kyky jäsentää ja tulkita todellisuutta kielellisesti parantuu koultuksen myötä - mikä edelleen lisää kykyä arvioida mielekkäästi koettua koulutustarvetta.

Tietämys siitä, miten kasvun, kehityksen tai elinolosuhteiden parantamisen tarpeet tiedostuvat ja jäsentyvät on vähäistä. Aikuiskasvatuk- sessa toısınaan iskulauseena todetaan "elämästä viriää oppimisen mieli ja suunta". Koetun koulutustarpeen teorianmuodostuksessa olisi tarkemmin pyrittävä selvittämään, miten elämä virittää oppimishalun ja miten se tai osa sitä kiteytyy koetuksi koulutustarpeeksi.

\section{LÄHTEET}

Forsberg, B. 1985. Vad måste vi lärä och varför? Arbetsrapporten från pedagogiska institutionen. Uppsala universitet 109.

Kaufman, R. \& English F. 1979. Needs Assessment: Concepts and applications. Englewood Cliff: Educational Techology.

Niiniluoto, I. 1983. Tieteellinen päättely ja selittäminen. Helsinki: Otava.

Scissons, E.H. 1982. A Typology of Needs Assessment Definitions in Adult Education. Adult Education $33,20-28$.

Varila, J. 1985a. Mitä on koettu koulutustarve koulutustarvetta ja erityisesti koettua koulutustarvetta kuvaavan ja selittävän käsitteistön jäsennys ja sen empiirinen sovellus. Aikuiskasvatuksen lisensiaattitutkimus. Helsingin yliopiston kasvatustieteen laitoksen kirjasto.

Varila, J. 1985b. Koetun koulutustarpeen käsite ja sen asema aikuisopiskelijan opetus-oppimisprosessia suunniteltaessa. Kontiainen, S. (toim.) Näkökulmia aikuiskoulutuksen tutkimukseen. Tutkimuksia ja tutkimussuunnitelmia. Helsingin yliopiston kasvatustieteen laitoksen tutkimuksia 107, 90-104.

\section{Virallisen tarkastajan lausunto}

Kasvatustieteiden osaston määräämänä lis. Juha Varilan väitöskirjaksi tarkoitetun tutkimuksen "Koetusta koulutustarpeesta ja sitä selittävistä tekijöistä" virallisena vastaväittäjänä esitän tutkimuksesta lausuntonani kunnioittaen seuraavaa:

Lis. Varilan tutkimus kohdistuu ongelma-alueeseen, joka aikuiskoulutuksen nykyisessä ekspansiovaiheessa ja opetusteoreettisten perspektiivien syvetessä kohti yhä tulkinnallisempaa koulutusnäkemystä on hyvin ajankohtainen. Koulutustarpeen arviointeja on suoritettu suomalaisessa aikuiskoulutuksessa runsaasti jo viime vuosikymmenellä ja sitä on käsitelty "teoreettisesti" monissa artikkeleissa. Sen olemuksen ja käsitteellisen rakenteen analysointi on kuitenkin jäänyt vähemmälle. Huomio on kiinnitetty mieluim- min tarpeen määrittelyn lähtökohtiin. On saatu aikaan metodisia ratkaisuja, joita sitten on ryhmitelty analyysitason tai tarpeen määrittäjän mukaan. Vasta uudempi sosiologinen, opetusteoreettinen ja työpsykologinen tarkastelutapa on johdattanut tutkijat syvällisempään koulutustarpeen käsiteanalyysiin.

Varila on tutkimuksessaan myös pyrkinyt syvällisempään koko koulutustarpeen ja varsinkin koetun koulutustarpeen käsitteen analyysiin. Hän on laajasti perehtynyt alan teoreettiseen kirjallisuuteen samoin kuin viimeaikaisiin tutkimusraportteihin. Koulutustarpeen kompleksisuudesta johtunee, ettei sen järjestelmällinen synteesiin tähtäävä käsittely ole tässäkään tutkimuksessa onnistunut. Vaikka tekijä ansiokkaasti osoittaakin alan kirjallisuuden tuntemuksensa, jää lopputulos referaa- tiksi, jossa luokitus toisensa jälkeen vyöryy lukijan eteen. Sen lisäksi tekijä ei suostu sitoutumaan mihinkään kuvailemistaan koulutustarpeen elementeistä, vaikka tutkimuksen paikantaminen empiirisen osan perusteella on täysin tehtävissä.

Koetun koulutustarpeen analyysi tiivistyy ja saa edellistä enemmän syvyyttä, vaikka tarpeen käsitteen analyysi jää kapeaksi ilman syvällisempää psykologista tarkastelua. Herääkin kysymys, onko koulutustarve sanan psykologisessa mielessä vai olisiko puhuttava koulutusodotuksista tai reaktiotaipumuksista hakeutua koulutukseen.

Tutkimuksen teoreettisessa analyysissä päädytään Scissonsin näkemykseen, ettei ole yhtä ainoaa oikeaa koultustarpeen määrittelytapaa. Tarveanalyysin tulos riip- 
puu siitä, mitä tarpeen määrittäjä painottaa tarvetta arvioidessaan ja miten hän tarpeen määrittää, mittauksin operationaalistaa. Tutkimuksen empiirisen osan lähtökohtana on Scissonsin koulutustarpeiden typologia. Vaikka tutkija onkin perehtynyt typologian perusteisiin perusteellisesti, olisi ollut syytä paneutua Scissonsin em. varoittaviin huomautuksiin syvällisemmin.

Tutkimuksen empiirinen osa jakaantuu kuvailevaan ja selittävään osaan. Kummankin osan pääongelmat ovat selkeitä ja tutkimuksen päätarkoituksen mukaisia. Kuvailevan osan alaongelmien suhteen voidaan tutkijan kanssa olla eri mieltä siitä, mikä tarvekomponenttien erilaisuutta tarkasteltaessa on relevanttia ja mielenkiintoista. Tutkija on valinnut erilaisuuden selvittämisen ydinkysymykseksi erojen sleivttämisen niden intensiteetissä. On ensinnä kysyttävä, voidaanko tarpeen voimakkuutta mitata kovin tarkalla mitta-asteikolla. Kykenemme verrattain karkeasti toteamaan, että tarpeet jollakin alueella ovat vahvemmat kuin toisella. Tutkija on kuitenkin käyttänyt 7-tasoista intensiteettiskaalaa, jossa tasojen vivahde-erot ovat hyvinkin tulkinnallisia ja itse asteikko toimii vain järjestysasteikon tasolla. Kunkin komponentin sisällön rakenne on pakotettu faktorianalyysin pääakselimentelmällä kaksiulotteiseksi, jotta intensiteettivertailu olisi helpompaa. Tämä menettely on täysin hyväksyttävä intensiteettierojen
Tehtäväosioiden arviointiasteikko olisi kuitenkin pitänyt laatia karkeampijakoiseksi ja sitä kautta yksiselitteisemmäksi.

Toinen kysymys onkin sitten, miksi ei tutkittu myös komponenttien rakenne-eroja käyttämällä tähän erilliseen tutkimusongelmaan faktorianalyysin pääkomponenttianalyysiä ja Varimax-rotaatiota tai vinorotaatiota. Näin kukin komponentti olisi saanut vapaasti avautua kutakin luonnehtiviin ulottuvuuksiin. Olisi nähty, jäsentyykö tehtäväavaruus eri tavoin, kun arvioidaan pätevyyttä, tärkeyttä ja opiskelumotivaatiota.

Selittävän osan pääongelmana oli tutkia, ovatko arvioitsijoiden näkemykset kasvatuksen ja kouluksen vaikuttavuudesta yhteydessä koetun koulutustarpeen intensiteettiin. Asetelma on toki mielenkiintoinen ts., onko koulutustarvearviointeja ohjaamassa arvioitsijoiden omaksuma kasvatus- ja koulutusasenteisto tai jopa jonkintasoinen filosofia. Hieman yllättävä oli tulos, että laaja-alaisempi ja ehkä epämääräisempi näkemys kasvatuksen vaikuttavuudesta selitti tarvearvionteja voimakkaammin kuin konkreettisempi näkemys koulutuksen vaikuttavuudesta. Yksi selitys voi löytyä mittareista. Niiden osioita analysoimalla jää vääjäämättä vaikutelma, että mittareiden nimet ovat vaihtuneet. Riippuvuudet selittäjien ja selitettävien välillä jäävät kovin pieniksi. Vaikka monet indeksit poikkesivatkin merkitsevästi nollasta, jäi niiden selitysprosentti alhaiseksi. Regressiona- lyysien merkitsevyyksien tulkintaa vie harhaan tekstiin jäänyt valitettava systemaattinen painovirhe. Multippelikertoimien (R) sijasta selitysvoimaa kuvaa sen toinen potenssi eli selitysprosentti.

Tutkimusraportissa on muutamia muitakin sisältöön liittyviä huolimattomuuksia, kuten Scissonsin typologian kuvion puutteellisuus (s. 30). Pahimpana puutteena lukijan kannalta voidaan kuitenkin pitää eräiden oleellisten liitteiden puuttumista, kuten taustamuuttujien varianssianalyysit ja faktorianalyysien kommunaliteettien puuttuminen.

Tutkimuksen ansiot ovat ennen kaikkea sen teoreettisessa osassa ja erityisesti koetun koulutustarpeen analyysissä. Enemmän puutteita ja pinnallisuutta löytyy empiirisessä toteutuksessa. Tutkija perustelee kyllä teknisellä syvällisyydellä metodivalintansa, mutta aineiston istuttaminen hyvin valittuun menetelmäkehikkoon jää pinnalliseksi, eikä lopputulos vastaa tutkijankaan ennakkohypoteeseja. Työn teoreettiset ansiot ja metodien tekninen hallinta painavat kuitenkin enemmän kuin empiirisen toteutuksen puutteet. Lis Varila puolusti väitöstilaisuudessa tutkimustaan hyvin.

Esitän mielihyvin kasvatusteiteiden osastolle, että lis. Juha Varilan tutkimus hyväksyttäisiin kasvatustieteen tohtorin arvoon oikeuttavana opinnäytteenä.

Jorma Ekola 